\title{
DEPOPULATION AND DEMOGRAPHIC AGING OF POPULATION: CASE STUDY MUNICIPALITY OF CRNA TRAVA
}

Filip Krstic ${ }^{* 1}$

"University of Belgrade - Faculty of Geography, Belgrade

\begin{abstract}
The municipality of Crna Trava is characterized by the most prominent demographic problems in the Republic of Serbia. The problem of depopulation and demographic aging of the population is one of the most important that Serbia faces and it represents one of the causes of regional inequalities. After the Second World War, the territory of the municipality of Crna Trava was affected by the great demogeographic changes that affected the transformation of this region. Demogeographic changes are clearly visible and are characterized by a decrease in the total population, population density and natural growth. As a consequence, there have been negative changes in the structural characteristics of the population. Depopulation is the dominant process, and the socio-economic situation in this municipality and the entire region does not provide opportunities for demographic and economic revitalization.
\end{abstract}

Key words: depopulation, demographic aging, rural areas, Crna Trava, agriculture.

\section{Introduction}

Demographic aging is a global phenomenon, and it is caused by the decline in fertility and the reduction of mortality in many countries and regions of the world. The share of the world's population older than 65 will be doubled between 2008 and 2040 (from 7.8\% to 14.7\%) (Schoeni and Ofstendal, 2010).

${ }^{1}$ Corresponding author: F. Krstić, University of Belgrade - Faculty of Geography, Studentski trg 3/III, 11,000 Belgrade, Serbia; e-mail: filipkrstic88@gmail.com 
The process of depopulation and demographic aging causes many economic problems, followed by problems in health care, the pension system and in the labour market. That is why the process of demographic aging is singled out as one of the biggest problems that the world's population will face. This problem requires a serious analysis and a long period of scientific research. This also represents the main scientific justification for the study of this phenomenon.

The problem of demographic aging and depopulation was dealt with by many domestic and foreign authors (Radivojević et al., 2016; Bacci, 2013; Coleman and Rowthorn, 2011; Demeny, 2011; Johnson, Layton and Poston, 2015; Kurek, 2011; Prioux et al. 2011; Rees et al. 2013). These scientific papers analyse the process of depopulation and aging from different perspectives, and with different aims: population trends, impact on economic trends, problems in health care of the population, international comparisons and the dynamics of depopulation and demographic aging and their various consequences.

Although the factors that lead to the depopulation process are related to the economic, social and technological transformation of the global society in the second half of the 20th century, its direct cause is of demographic nature. A negative natural increase may be the result of low fertility rates (as is the case in many European countries). Total fertility rates in the countries of the European Union have decreased from 2.5 live-born children per woman in 1961 to just 1.6 in 2011 (Brandmüller and Önnerfors, 2011). Changes in the age structure of the population is another explanation for the depopulation process and the negative natural increase. The disruption in the age structure of Europe's population was mainly due to intensive migrations or the process of emigration of the fertile contingent of population (Johnson, et al., 2015).

In the second half of the $20^{\text {th }}$ century and in the first decades of the $21^{\text {st }}$ century, Serbia was faced with negative demographic changes. Negative demographic processes are marked by depopulation, negative natural increase, aging of the population, negative migration balance and the reduction of the fertile and labour force population contingent. Both process of depopulation and demographic aging are long-lasting with the tendency of increasing already existing disproportions. Therefore, it can be concluded that there are extremely unfavourable demographic conditions that determine further unfavourable tendencies in the demographic development of Serbia. The process of aging of the population in Serbia took place simultaneously from the top of the population pyramid (increasing the share of the older population and extending the life expectancy) and from the base of population pyramid (by reducing the share of the young population due to the negative natural increase). 
Regionally, the aging process is the most intensive in the region of South and East Serbia. The average age of the population in this region according to the 2011 Census is 43.3 years (while the average for the Republic of Serbia is 42.2 years). The intensive aging of generations born in the compensatory period after the Second World War will lead to further deterioration of the age structure of the population.

\section{Territorial Framework of the Research}

The territorial framework of the research is the municipality of Crna Trava $\left(318 \mathrm{~km}^{2}\right)$, located in the southeastern part of Serbia, in the geographical region of Vlasina. The territory of the municipality is identified with the eponymous microregion called Crna Trava. According to the Spatial plan of Republic of Serbia the municipality of Crna Trava is a part of the functional area of the Jablanica District. In addition to Crna Trava, the Jablanica District also includes the territories of the municipalities of Bojnik, Medveđa, Lebane, Vlasotince and the City of Leskovac, which has the role of the main functional center.

The municipality has an unfavourable transport and geographical position. It is located peripherally regarding to the main road and railway routes leading through the Morava-Vardar valley (Pan-European corridor X). The municipality has 25 rural settlements, in which according to the 2011 census, there were only 1663 inhabitants. This makes the municipality of Crna Trava the least populous municipality in the Republic of Serbia. The municipality of Crna Trava does not have an urban settlement on its territory, so the village of Crna Trava has the function of municipal centre.

The territory of the municipality is located in the border region with Bulgaria. The peripheral geographical position as well as the transport isolation and poor transport infrastructure of this territory has additionally intensified the problem of depopulation and demographic aging of the population. According to Radovanović and Gigović, the low population density and the process of depopulation can be also explained by the barrier function of the state border, which influenced on increased emigration of the population from this area (Радовановић and Гиговић 2010). The small population density of only 5 people per $\mathrm{km}^{2}$, indicates an insufficient economic space utilization. Physical-geographical conditions, i.e. the dominant mountain relief, as well as socio-historical development of this region have influenced on the dispersive distribution of the population and the appearance of small rural villages (with less than 100 inhabitants). 


\section{Methodology and Data}

The main scientific methods used in this paper are: statistical method, analytical-synthesis method and comparative method. The scientific analysis carried out in this paper is based on the use of theoretical and empirical literature, as well as on the interpretation of data collected from statistical sources. Bearing in mind that the process of depopulation is affected by the natural growth and migration of the population, as well as by various external factors - economic, socio-cultural, health and other. Both the depopulation and demographic aging are a long-term process; hence the statistical analysis refers to the period after the Second World War. The primary data used in the work are the Census data for the age structure of the population.

Such methodological approach enables a complex analysis of the spatial and temporal components of the process of depopulation and demographic aging. It also enables the examination of the consequences of the polarization of population and economic activities in the territory of Serbia.

\section{Results and Discussion}

The period after the Second World War on the territory of Serbia was characterized by three mutually conditioned processes - industrialization, urbanization and deagrarization. These processes have led to the creation of socio-economic inequalities, both between urban and rural areas and between different regions in Serbia. Demographic processes in rural areas, such as the Crna Trava region, have had a negative impact on the economic and, above all, on agricultural development.

In the period between 1948-2011, the number of inhabitants in the settlements of the municipality of Crna Trava is in constant decline. Crna Trava is one of the few municipalities in Serbia where the process of depopulation started immediately after the Second World War. In the compensatory period after the Second World War (1948-1953), there was no increase in the number of inhabitants in this municipality. In the period 1948-2011 the total drop in the number of inhabitants was 11,951. In this period the number of inhabitants decreased by $87.8 \%$. Especially the depopulation process was intensified in the period between 1961-1991 when the negative average growth rates were around $-50 \%$. 
Depopulation and Demographic Aging of Population: Case Study Municipality of Crna Trava

Table 1 - Population of the municipality of Crna Trava and the settlement of Crna Trava for the period 1948-2011

\begin{tabular}{|l|c|c|c|c|c|c|c|c|}
\hline \multicolumn{1}{|c|}{ Year } & $\mathbf{1 9 4 8}$ & $\mathbf{1 9 5 3}$ & $\mathbf{1 9 6 1}$ & $\mathbf{1 9 7 1}$ & $\mathbf{1 9 8 1}$ & $\mathbf{1 9 9 1}$ & $\mathbf{2 0 0 2}$ & $\mathbf{2 0 1 1}$ \\
\hline $\begin{array}{l}\text { Municipality } \\
\text { Crna Trava }\end{array}$ & 13,614 & 12,902 & 12,319 & 9,672 & 6,366 & 3,789 & 2,563 & 1,663 \\
\hline $\begin{array}{l}\text { Settlement } \\
\text { Crna Trava }\end{array}$ & 2,051 & 1,860 & 1,639 & 1,276 & 873 & 688 & 563 & 434 \\
\hline
\end{tabular}

Source: Републички завод за статистику, 2012.

The intensity of the depopulation process is also indicated by the fact that the Crna Trava settlement also recorded a decline in the number of inhabitants in all census periods after the Second World War. Although this settlement represents a municipal center, it did not attract the population from the territory of its municipality via migration, unlike other municipal centers on the territory of Serbia. After 1971, the migration from the urban to the rural areas was intensified. These migrations were directed towards urban and economic centers outside the borders of the region - Leskovac, Niš and Belgrade. Long-term emigration of the fertile population has had negative consequences on the demographic development of this municipality. Villages of Bajinci, Bankovci, Bistrica, Dobro polje, Jovanovci, Ostrozub, Pavličina, Rajčetina and Čuka are demographically most endangered, as they were left without inhabitants who are under the age of 25 .

The demographic aging process is the result of a decline in the share of the young population due to the negative natural increase, but also the prolongation of the life expectancy of the population after the Second World War. The region of South and East Serbia has been affected by the most intensive process of demographic aging in Serbia.

Table 2 - Age structure of population of Crna Trava municipality in 1961 and 2011

\begin{tabular}{|c|c|c|c|}
\hline Year & $\mathbf{0}-\mathbf{1 4}$ years $\mathbf{( \% )}$ & $\mathbf{1 5}-\mathbf{6 4}$ years $\mathbf{( \% )}$ & $\mathbf{6 5}$ or more years $\mathbf{( \% )}$ \\
\hline 1961 & 31.6 & 62.0 & 6.4 \\
\hline 2011 & 6.1 & 57.7 & 36.2 \\
\hline
\end{tabular}

Source: Републички завод за статистику, 2012; Савезни завод за статистику, 1965.

The mutual causality of the depopulation process and the negative changes in the age structure in the direction of increasing population aging 
are best seen on the basis of data regarding to the main age groups of the population. The share of the young population up to 15 years of age shows a marked decline in the study period (from $31.6 \%$ in 1961 to $6.1 \%$ in 2011). The number of working-age population also declined from $62.0 \%$ to $57.7 \%$. Between 1961 and 2011, the share of the old population was markedly increased, from $6.4 \%$ to $36.2 \%$. The average age of the population on the territory of the municipality of Crna Trava in 2011 was 53.7 years.

In order to examine the process of population aging at the municipal level, it is necessary to determine the aging index and the stage of demographic age (according to Penev method, Penev, 1995). According to the 1961 census, the population of the municipality of Crna Trava was in the third stage of demographic age - the stage of demographic maturity (aging index 25). However, in 2011, the population of this municipality is at the last, seventh stage - deep demographic old age (aging index 435).

In the observed period, birth rates in the territory of the municipality decreased from $24.2 \%$ o to just $4.3 \%$, and the rate of natural increase, or natural depopulation to be more precise, was reduced from $16.7 \%$ o to $-31.9 \%$ o (we should mention the year 2010 when the rate of natural depopulation was as high as $-47.1 \%$ ). General mortality rates in the first decades after the Second World War have been decreasing, which is associated with better health protection of the population and reduction in the rate of infant mortality. However, due to the gradual aging of the population after 1975, there is an increase in the mortality rate. The modernization of society after the Second World War caused a long-term process of reducing birth rates (the process of industrialization, urbanization, the spread of education and health care, etc.). Simultaneously with the process of demographic transition, a transition from a traditional type of family occurred. So today a modern "nuclear" type of family is dominant. Such a pronounced fall in natural growth can be brought in connection with the intensive migration of the young population, or with the loss of a fertile contingent.

Industrialization in the large urban settlements of South Serbia led to an accelerated emigration of the population from the Crna Trava region and the process of deagrarization. The migration movements in the territory of the municipality of Crna Trava, as well as the entire border area with Bulgaria, had a significantly greater influence on the age structure of the population than in other parts of Serbia (Радовановић and Гиговић, 2006). 
Table 3 - Natural change of population in the municipality of Crna Trava for the period 1961-2015

\begin{tabular}{|c|c|c|c|c|c|c|}
\hline \multirow{2}{*}{ Year } & \multirow{2}{*}{$\begin{array}{c}\text { Live } \\
\text { births }\end{array}$} & \multirow{2}{*}{ Deaths } & \multirow{2}{*}{$\begin{array}{c}\text { Natural } \\
\text { change }\end{array}$} & \multicolumn{3}{|c|}{ Rates per 1000 residents } \\
\cline { 5 - 7 } & & & Birth & Death & Natural change \\
\hline 1961 & 298 & 93 & 205 & 24.2 & 7.5 & 16.7 \\
\hline 1970 & 142 & 80 & 62 & 14.3 & 8.1 & 6.2 \\
\hline 1980 & 65 & 90 & -25 & 9.7 & 13.4 & -3.7 \\
\hline 1990 & 28 & 96 & -54 & 6.9 & 20.3 & -13.4 \\
\hline 2000 & 13 & 56 & -43 & 4.6 & 19.9 & -15.3 \\
\hline 2010 & 6 & 79 & -73 & 3.9 & 50.9 & -47.1 \\
\hline 2015 & 6 & 51 & -45 & 4.3 & 36.2 & -31.9 \\
\hline
\end{tabular}

Source: Републички завод за статистику, 2012; Општине и региони у Републици Србији, 2016.

The decline in fertility and the continuously negative migration balance caused negative changes in the age structure of the population. It should also be noted that the process of deagrarization after the Second World War has disturbed the human sex ratio of the population in this microregion, causing gender unbalance. In 1961, women's population was more numerous in rural settlements of the region. The reason for this is the economic migration in which the male population was mainly involved. In later phases of deagrarization, the female members of the population took part in emigration and in departure from agriculture and rural settlements (for education and employment in the secondary and tertiary-quaternary sector of the economy). These migrations lead to an increase in the proportion of female population in urban areas, and to a decrease in rural areas (the proportion of male population in the municipality of Crna Trava according to the 2011 Census data was 58\%).

\section{The consequences of the depopulation process on the development of agriculture}

The territory of the municipality of Crna Trava is economically underdeveloped, with an unfavourable structure of the agricultural land, in which the largest areas are under meadows and pastures. In accordance with natural resources, the population has always been directed towards extensive livestock production. Such natural conditions influenced the occurrence of 
seasonal economic migrations. Over time, these migrations have become permanent and have affected the intensive process of depopulation.

Demographic processes in the region of Crna Trava caused significant physiognomic, functional and socioeconomic transformations. Among the most prominent indicators of negative spatial processes is the phenomenon of non-cultivation and abandonment of agricultural land. Non-cultivation of agricultural land is a consequence of the lack of labour force, due to the emigration of the labour-productive population and the overall aging of the population. Agricultural areas are therefore left to wild vegetation, which is best shown by the data from Table 4 . The abandonment of rural households leads to the depletion of agricultural areas, which are mainly represented by meadows and pastures. Due to the lack of labour force, there was a significant decline in the agrarian density of the population. In 1971 the agrarian population density in this municipality was 55.1 people per 100 ha, and in 2011 it was only 10.6 people per 100 ha.

Table 4 - Structure of the agricultural area of Crna Trava municipality in 1974 and 2016

\begin{tabular}{|l|c|c|c|c|}
\hline \multirow{2}{*}{ Category of agricultural area } & \multicolumn{2}{|c|}{1974} & \multicolumn{2}{c|}{2016} \\
\cline { 2 - 5 } & ha & \% & ha & \% \\
\hline Arable crop fields & 2,625 & 15.2 & 844 & 5.4 \\
\hline Orchards & 223 & 1.3 & 340 & 2.2 \\
\hline Vineyards & 1 & 0.1 & 0 & 0 \\
\hline Meadows & 6,946 & 40.2 & 7,070 & 45.6 \\
\hline Pastures & 7,486 & 43.3 & 7,246 & 46.8 \\
\hline Total arable land & 9,795 & 56.7 & 8,261 & 53.3 \\
\hline Total agricultural land & 17,281 & 100 & 15,507 & 100 \\
\hline
\end{tabular}

Source: Општине и региони у републици Србији.

Agricultural production in the region of Crna Trava, in which dominates livestock breeding, is poorly developed and inadequately organized. The most important problem facing agriculture is demographic, i.e. lack of labour force, a large number of old age and single-member households and generally unfavourable age structure of the population. Insufficient production compliance, underdevelopment of processing facilities in the food industry, obsolescence of mechanization, fragmentation of arable land areas and insufficient organization of farmers in production, processing and placing on the market are among the problems. 
Contemporary demographic processes have mostly affected the development of livestock farming, the traditional branch of agriculture in this region. They are reflected in the devastion of traditional animal husbandry, and the decline in livestock production. Sheep breeding has the best natural conditions for development, however, the number of livestock shows a significant decrease in the last decades (Table 5).

Table 5 - Changes in the number of livestock of Crna Trava municipality in 1974 and 2016

\begin{tabular}{|l|c|c|}
\hline Category & $\mathbf{1 9 7 4}$ & $\mathbf{2 0 1 6}$ \\
\hline Sheep & 6,741 & 1,288 \\
\hline Cattle & 5,494 & 309 \\
\hline Pigs & 1,911 & 1,42 \\
\hline Poultry & 19,836 & 5,016 \\
\hline
\end{tabular}

Source: Општине и региони у републици Србији.

\section{Conclusion}

The municipality of Crna Trava is the first in which the phenomenon of depopulation after the Second World War in Serbia was recorded. The causes of this unfavourable socio-economic situation are very complex and long-term. The main factors of the process of depopulation and demographic aging are: emigration of the fertile population contingent, i.e. direct and indirect consequences of the emigration process; the process of industrialization in which the concentration of industry in urban settlements outside the studied territory occurred. This has led to accelerated and unorganized process of deagrarization; unfavourable agrarian policy, which did not encourage the staying of the young population in rural areas and the undeveloped infrastructure on the territory of the municipality of Crna Trava.

The studied demographic processes influenced on the changes in the age structure of the population, especially the aging process of certain age groups - female fertile population and work-force population. This leads to a decrease in labour force, which negatively affects the economic development of the Crna Trava region. The unfavourable age structure of the population had a negative impact on central functions in rural settlements (closing of trade and market facilities, schools, ambulances, post office, etc.). The settlement of Crna Trava did not become the economic and population 
centre of the municipality of the same name. Lack of central and administrative functions and job offers did not lead to the transformation of this settlement and its gravitational zone. This is one of the reasons that led the rural exodus of the population towards larger economic centres (Leskovac, Niš, Belgrade, etc.). The physiognomy of rural settlements in the region of Crna Trava points to economic underdevelopment, as well as to very poor infrastructure. A large number of houses are abandoned, while new object of infrastructure and housing almost do not exist. Reducing the demographic potential of the region, i.e. demographic aging, the population experienced a downturn in the economic development, primarily in agriculture.

\section{Acknowledgements}

The paper is the result of the research within the project no. 176008 funded by the Ministry of Education and Science of the Republic of Serbia.

\section{References}

Bacci, M. (2013). Low Fertility in Historical Perspective. Population and Development Review, 38, 72-82.

Brandmüller, T. and Åsa Ö. (eds.). 2011. Eurostat Regional Yearbook 2011. Luxembourg: Publications Office of the European Union.

Coleman, D., \& Rowthorn, R. (2011). Who's Afraid of Population Decline? A Critical Examination of Its Consequences. Population and Development Review, 37, 217-248.

Demeny, P. (2011). Population Policy and the Demographic Transition: Performance, Prospects, and Options. Population and Development Review, 37, 249-274.

Johnson, K., Layton, F. and Poston Jr., D. (2015). More deaths than births: subnational natural decrease in Europe and the United States. Population and Development Review, 41 (4), 651 - 680.

Kurek, S. (2011). Double transitions? Regional patterns of population ageing in Poland. Geografiska Annaler. Series B, Human Geography, 93(2), 163-184.

Penev, G. (1995). Stanovništvo po polu i starosti. In Stanovništvo i domaćinstva SR Jugoslavije prema popisu 1991. godine, ed. Zoran Jovanović Beograd: Savezni zavod za statistiku and Centar za demografska istraživanja Instituta društvenih nauka, 167-69.

Prioux, F., Tabutin, D., Toulemon, L., Avdeev, A., Eremenko, T., Festy, P., ... 
Wiles-Portier, E. (2011). Populations and Demographic Trends of European Countries, 1980-2010. Population (English Edition, 2002-), 66(1), 7-129.

Radivojević, A., Pavlović, M., Milovanović, M., Stričević, Lj. and Dimić, M. (2016). Population Aging in Serbia: A case study of the Municipality of Bela Palanka. Journal of Family History, 41(2), 165-175.

Rees, P., Zuo C., Wohland P., Jagger C., Norman P., Boden P. and Jasinska M. (2013). The implications of ageing and migration for the future population, health, labour force and households of Northern England. Appl. Spatial Analysis 6, 93-122

Schoeni, R. and Ofstedal, M. (2010). Key themes in research on the demography of aging. Demography, 47, S5-S15.

Општине и региони у Републици Србији 1974-2016, Републички завод за статистику Београд.

Радовановић, С. и Гиговић Љ. (2010). Демографски процеси у пограничном простору Србије према Бугарској. Демографија, 7, 105 - 128.

Републички завод за статистику (2012). Књига 20: Упоредни преглед броја становника 1948 - 2011. Београд: РЗС.

Републички завод за статистику (2012). Природно кретање становништва у Републици Србији 1961-2010. Београд: РЗС.

Савезни завод за статистику (1965). Попис становништва 1961. Пол и старост, књига 11. Београд: Савезни завод за статистику. 